The precise cause of acute renal failure in leptospirosis is not well understood. Bacterial toxin and renal anoxia secondary to haemodynamic changes are among the possibilities thought to account for renal failure (Areán, 1962). Since there was a significant association between renal failure and jaundice in group 1, impaired renal function is evaluated in light of the hepatorenal syndrome. In this syndrome renal failure is attributed to renal haemodynamic changes secondary to liver failure. Though jaundice was intense in this group, liver-function tests showed only slight impairment in function. The striking contrast between the severity of clinical manifestations and the slight deviation of liver function in leptspirosis is well appreciated (Areán and Henry, 1964). In the absence of liver failure the hepatorenal syndrome seems unlikely. Finally, the possibility of the toxic effect of bile on the kidney is raised. It is not known to what extent bilirubin plays a part in renal function. Recently it has been shown that intravenous injection of bilirubin in dogs results in a decrease in tubular reabsorption of sodium (Topuzlu and Stahl, 1966). As some patients in the report of Stiles et al. (1946) and one in this report (Case 2) developed renal failure without jaundice, it would seem unlikely that impaired renal function is secondary to jaundice.

Because of a tendency towards bleeding during the acute period of illness renal biopsy was not attempted. In a series of renal biopsies performed late in the course of disease the pathological changes were suggestive of a mild degree of acute tubular necrosis and interstitial nephritis (Penna et al., 1963). The results of renal function study in group 1 support the above pathological findings. The study by electronmicroscopy showed focal thickening of basement membrane, fusion of foot processes, loss of brush border, and mitochondrial depletion of renal tubules (DeBrito et al., 1965).

Since dehydration very often cannot be clinically detected, intravenous fluid therapy may be dangerous when the cause of azotaemia is not known. From this study, for practical purposes, fluid administration in azotaemic patients with leptospirosis should be based on the serum creatinine and Uosm/ Posm. When the serum creatinine is above $2 \mathrm{mg} . / 100 \mathrm{ml}$. and Uosm/Posm is close to 1 azotaemia is most likely due to acute tubular necrosis, and excessive fluid therapy should be avoided. Conversely, when the serum creatinine is below $2 \mathrm{mg} . / 100 \mathrm{ml}$. and Uosm/Posm approximates 2 dehydration should be sus pected, and fluid load would be the treatment of choice.

\section{Summary}

Renal function was studied in 10 azotaemic patients with proved leptospirosis. In five patients azotaemia was ascribed to parenchymal renal failure of acute tubular necrosis. In this group the serum creatinine was higher than $2 \mathrm{mg} . / 100 \mathrm{mi}$. and the osmotic urine and plasma ratio averaged 1.24 , indicating a defect in renal concentration. In another group of five patients the renal function study suggested that volume deficit or dehydration might be the cause of azotaemia. The serum creatinine was lower than $2 \mathrm{mg} . / 100 \mathrm{ml}$. and the mean osmotic urine and plasma ratio was 2.35 . In both groups there was a decrease in endogenous creatinine and para-aminohippurate clearances; the decrease was more pronounced in group 1. Because of the clinical inaccuracy in detecting dehydration the serum creatinine and the osmotic urine and plasma ratio may be used as a clue in ascertaining the cause of azotaemia, and thus provide useful information regarding the fluid therapy of azotaemic patients with leptospirosis.

\section{REFERENCES}

Areán, V. M. (1962). Amer. F. Path., 40, 393.

Areán, V. M., and Henry, J. B. (1964). Amer. F. trop. Med. Hyg., 13, 430 .

Bradley, S. E., Bradley, G. P., Tyson, C. J., Curry, J. J., and Blake, W. D. (1950). Amer. F. Med., 9, 766.

Cargill, W. H. (1949). 7. clin. Invest., 28, 533.

Cora, D. (1956). G. clin. med., 37, 1295.

DeBrito, T., et al. (1965). Amer. f. trop. Med. Hyg., 14, 397.

Edwards, G. A. (1959). Amer. F. Med., 27, 4.

Eliahou, H. E., and Bata, A. (1965). Nephron, 2, 287.

Eliahou, H. E., and Bata, A. (1965). Neph
Gsell, O. (1952). Leptospirosen. Berne.

Meroney, W. H., and Rubini, M. E. (1959). Metabolism, 8, 1.

Moore, F. D., Ölesen, K. H., McMurrey, J. D., Parker, H. V., Ball M. R., and Boyden, C. M. (1963). The Body Cell Mass and Its Supporting Environment, p. 72. Philadelphia and London.

Penna, D., DeBrito, T., Aguiar, Pupo, A., Marcondes Machado, M, Ayroza, Galvão, P. A., and Soares De Almeida, S. (1963). Amer. trop. Med. Hyg., 12, 896.

Sitprija, V. (1968). Med. Today. In press.

Sitprija, V., Indraprasit, S., Pochanugool, C. Benyajati, C., and Piyaratm, P. (1967). Lancet, 1, 185.

Smith, H. W. (1966). Principles of Renal Physiology. New York.

Stiles, W. W., Goldstein, J. D., and McCann, W. S. (1946). f. Amer. med. Ass., 131, 1271 .

Topuzlu, C., and Stahl, W. M. (1966). New Engl. f. Med., 274, 760.

\title{
Fibrinolytic Response to Moderate Exercise in 50 Healthy Middle-aged Subjects
}

\author{
J. D. CASH,* M.B., CH.B., B.SC., PH.D., M.R.C.P.ED. ; D. G. W'OODFIELD, † M.B., CH.B., M.R.C.P.ED.
}

Brit. med. F., 1968, 2, 658-661

Previous studies reported from this laboratory on the fibrinolytic response to a short period of moderate exercise in a group of normal young subjects showed a small subgroup whose response to this procedure was poor (Cash, 1966). A similar pattern was also demonstrated when intravenous adrenaline was used as a fibrinolytic stimulant, so that a poor responder to moderate exercise was also a poor responder to intravenous adrenaline (Cash and Allan, 1967). These results led us to conclude that one interpretation of this phenomenon could be a fundamental defect in the mechanisms related to the release of plasminogen activator in an acute stressful situation, and that the subgroup which displayed this anomaly might be at risk to conditions such as atherosclerosis, thrombosis, and

\footnotetext{
- Senior Registrar.

+ Registrar.

South-east Scotland Regional Blood Transfusion Research Laboratorien Royal Infirmary, Edinburgh 3.
}

irreversible shock in which defective fibrinolysis has been postulated to be an important aetiological factor (Astrup, 1956; Hardaway, 1966).

The original exercise observations were made on a group of 50 young healthy subjects aged $18-30$ (mean 22.3 ) years. The following communication describes the results from a group of 50 healthy middle-aged volunteers, obtained during the period in which the young subjects were studied, and also a limited 12-month follow-up study on 18 selected middle-aged subjects.

\section{Subjects}

The subjects were 25 male and 25 female blood donors aged 42-57 (mean 49.6) years. All agreed to give a detailed medicel history and submit themselves to a full clinical examination, which included a resting (supine 15 minutes) blond pressure (by 
arscultation), postprandial urine analysis for sugar and albumin, and 2 routine resting and post-exercise (two minutes' step-up test) 12-lead electrocardiograph. No significant clinical abnor-

TABLE I.-Euglobulin Lysis Times Before and After Moderate Exercise in 50 Healthy Middle-aged Male and Female Subjects

\begin{tabular}{|c|c|c|c|c|c|c|c|}
\hline \multirow{3}{*}{\begin{tabular}{c|} 
Sub- \\
ject \\
No.
\end{tabular}} & \multicolumn{3}{|c|}{ Males } & \multirow{3}{*}{$\begin{array}{c}\text { Subject } \\
\text { No. }\end{array}$} & \multirow{2}{*}{\multicolumn{3}{|c|}{$\frac{\text { Females }}{\text { Euglobulin Lysis Time }}$}} \\
\hline & \multicolumn{3}{|c|}{ Euglobulin Lysis Time } & & & & \\
\hline & Before & After & $\begin{array}{c}\text { Increase } \\
(\%)\end{array}$ & & Before & After & $\begin{array}{c}\text { Increase } \\
(\%)\end{array}$ \\
\hline M I* & $\begin{array}{l}924 \\
989 \\
747 \\
800 \\
\end{array}$ & $\begin{array}{l}759 \\
999 \\
689 \\
690 \\
\end{array}$ & $\left.\begin{array}{r}18 \\
0 \\
8 \\
14\end{array}\right\} 10$ & F $\quad 1 * t$ & $\begin{array}{l}180 \\
159 \\
148\end{array}$ & $\begin{array}{l}97 \\
77 \\
83\end{array}$ & $\left.\begin{array}{l}46 \\
52 \\
44\end{array}\right\} 47$ \\
\hline $\mathbf{M} \mathbf{2}^{*}$ & $\begin{array}{l}220 \\
160 \\
239 \\
324 \\
\end{array}$ & $\begin{array}{l}101 \\
110 \\
116 \\
139 \\
\end{array}$ & $\left.\begin{array}{l}54 \\
31 \\
52 \\
57\end{array}\right\} 49$ & F $2+$ & $\begin{array}{l}367 \\
262\end{array}$ & $\begin{array}{r}112 \\
69\end{array}$ & $\left.\begin{array}{l}70 \\
74\end{array}\right\} 72$ \\
\hline M 3 & $\begin{array}{l}127 \\
122 \\
270 \\
\end{array}$ & $\begin{array}{r}45 \\
61 \\
107 \\
\end{array}$ & $\left.\begin{array}{l}65 \\
50 \\
60\end{array}\right\} 58$ & F $3 t$ & $\begin{array}{r}105 \\
86\end{array}$ & $\begin{array}{l}37 \\
35\end{array}$ & $\left.\begin{array}{l}65 \\
59\end{array}\right\} 62$ \\
\hline M 4 & $\begin{array}{l}118 \\
107 \\
102 \\
\end{array}$ & $\begin{array}{l}71 \\
70 \\
68 \\
\end{array}$ & $\left.\begin{array}{l}40 \\
35 \\
33\end{array}\right\} 36$ & F $4 t$ & $\begin{array}{l}210 \\
127\end{array}$ & $\begin{array}{r}119 \\
65\end{array}$ & $\left.\begin{array}{l}43 \\
49\end{array}\right\} 46$ \\
\hline M 5 & $\begin{array}{l}75 \\
82 \\
\end{array}$ & $\begin{array}{l}33 \\
35 \\
\end{array}$ & $\left.\begin{array}{l}56 \\
57\end{array}\right\} 57$ & F $5^{*}$ & $\begin{array}{l}95 \\
87 \\
\end{array}$ & $\begin{array}{l}45 \\
45 \\
\end{array}$ & $\left.\begin{array}{l}53 \\
48\end{array}\right\} 51$ \\
\hline M $6^{*}$ & $\begin{array}{l}208 \\
228 \\
\end{array}$ & $\begin{array}{l}103 \\
107 \\
\end{array}$ & $\left.\begin{array}{l}50 \\
53\end{array}\right\} 52$ & F $6 *$ & $\begin{array}{l}118 \\
176 \\
\end{array}$ & $\begin{array}{l}48 \\
49 \\
\end{array}$ & $\left.\begin{array}{l}59 \\
72\end{array}\right\} 66$ \\
\hline M 7 & $\begin{array}{l}120 \\
107\end{array}$ & $\begin{array}{l}78 \\
80\end{array}$ & $\left.\begin{array}{l}35 \\
25\end{array}\right\} 30$ & F 7 & $\begin{array}{r}220 \\
113 \\
153 \\
98 \\
\end{array}$ & $\begin{array}{l}83 \\
70 \\
68 \\
57 \\
\end{array}$ & $\left.\begin{array}{l}62 \\
38 \\
66 \\
42\end{array}\right\} 52$ \\
\hline M 8 & $\begin{array}{r}159 \\
95 \\
\end{array}$ & $\begin{array}{l}79 \\
52 \\
\end{array}$ & $\left.\begin{array}{l}50 \\
45\end{array}\right\} 48$ & F $8 t$ & $\begin{array}{l}120 \\
235 \\
\end{array}$ & $\begin{array}{l}30 \\
65 \\
\end{array}$ & $\left.\begin{array}{l}75 \\
72\end{array}\right\} 74$ \\
\hline$M 9^{*}$ & $\begin{array}{l}123 \\
147 \\
106 \\
\end{array}$ & $\begin{array}{l}50 \\
72 \\
56 \\
\end{array}$ & $\left.\begin{array}{l}59 \\
51 \\
47\end{array}\right\} 52$ & F 9 & $\begin{array}{r}90 \\
120 \\
103 \\
\end{array}$ & $\begin{array}{l}55 \\
90 \\
71 \\
\end{array}$ & $\left.\begin{array}{l}39 \\
25 \\
31\end{array}\right\} 32$ \\
\hline M 10 & $\begin{array}{l}288 \\
201\end{array}$ & $\begin{array}{r}135 \\
96\end{array}$ & $\left.\begin{array}{l}53 \\
52\end{array}\right\} 53$ & F 10 & $\begin{array}{l}101 \\
115 \\
100 \\
\end{array}$ & $\begin{array}{l}40 \\
48 \\
42 \\
\end{array}$ & $\left.\begin{array}{l}60 \\
58 \\
58\end{array}\right\} 59$ \\
\hline M 11 & $\begin{array}{l}113 \\
100\end{array}$ & $\begin{array}{l}68 \\
66\end{array}$ & $\left.\begin{array}{l}40 \\
34\end{array}\right\} 37$ & $\mathrm{~F} 11^{*}$ & $\begin{array}{l}233 \\
152 \\
225 \\
\end{array}$ & $\begin{array}{l}90 \\
62 \\
75 \\
\end{array}$ & $\left.\begin{array}{l}61 \\
59 \\
67\end{array}\right\} 62$ \\
\hline M 12* & $\begin{array}{l}98 \\
84 \\
75 \\
58\end{array}$ & $\begin{array}{l}48 \\
54 \\
46 \\
28\end{array}$ & $\left.\begin{array}{l}51 \\
36 \\
39 \\
52\end{array}\right\} 45$ & $F 12 * t$ & $\begin{array}{l}578 \\
412 \\
816 \\
741 \\
\end{array}$ & $\begin{array}{l}566 \\
275 \\
877 \\
568 \\
\end{array}$ & $\left.\begin{array}{r}2 \\
33 \\
0 \\
23\end{array}\right\} 15$ \\
\hline M 13 & $\begin{array}{l}538 \\
126\end{array}$ & $\begin{array}{r}284 \\
59\end{array}$ & $\left.\begin{array}{l}47 \\
53\end{array}\right\} 50$ & F 13 & $\begin{array}{r}84 \\
84 \\
105 \\
\end{array}$ & $\begin{array}{l}44 \\
48 \\
53\end{array}$ & $\left.\begin{array}{l}48 \\
43 \\
50\end{array}\right\} 47$ \\
\hline M 14 & $\begin{array}{l}176 \\
682\end{array}$ & $\begin{array}{r}96 \\
383\end{array}$ & $\left.\begin{array}{l}46 \\
44\end{array}\right\} 45$ & F 14 & $\begin{array}{l}85 \\
89 \\
160 \\
\end{array}$ & $\begin{array}{l}51 \\
49 \\
87\end{array}$ & $\left.\begin{array}{l}40 \\
45 \\
46\end{array}\right\} 44$ \\
\hline M 15 & $\begin{array}{r}90 \\
237\end{array}$ & $\begin{array}{r}40 \\
110\end{array}$ & $\left.\begin{array}{l}56 \\
54\end{array}\right\} 55$ & F 15 & $\begin{array}{l}102 \\
221 \\
111 \\
112 \\
\end{array}$ & $\begin{array}{r}53 \\
140 \\
59 \\
54 \\
\end{array}$ & $\left.\begin{array}{l}48 \\
37 \\
47 \\
52\end{array}\right\} 46$ \\
\hline M 16* & $\begin{array}{r}93 \\
95 \\
101 \\
\end{array}$ & $\begin{array}{l}60 \\
51 \\
56 \\
\end{array}$ & $\left.\begin{array}{l}36 \\
46 \\
45\end{array}\right\} 42$ & F $16 * t$ & $\begin{array}{l}200 \\
212\end{array}$ & $\begin{array}{l}73 \\
81\end{array}$ & $\left.\begin{array}{l}64 \\
62\end{array}\right\} 63$ \\
\hline M 17 & $\begin{array}{l}641 \\
765 \\
840 \\
700 \\
\end{array}$ & $\begin{array}{l}301 \\
660 \\
602 \\
351 \\
\end{array}$ & $\left.\begin{array}{l}53 \\
14 \\
28 \\
50\end{array}\right\} 36$ & F 17t & $\begin{array}{l}69 \\
61\end{array}$ & $\begin{array}{l}41 \\
34\end{array}$ & $\left.\begin{array}{l}41 \\
44\end{array}\right\} 43$ \\
\hline M 18 & $\begin{array}{r}144 \\
95 \\
\end{array}$ & $\begin{array}{l}96 \\
63 \\
\end{array}$ & $\left.\begin{array}{l}33 \\
34\end{array}\right\} 34$ & F $18 * t$ & $\begin{array}{l}940 \\
449 \\
\end{array}$ & $\begin{array}{l}484 \\
187\end{array}$ & $\left.\begin{array}{l}49 \\
58\end{array}\right\} 54$ \\
\hline M 19 & $\begin{array}{r}65 \\
105 \\
\end{array}$ & $\begin{array}{l}34 \\
55 \\
\end{array}$ & $\left.\begin{array}{l}48 \\
48\end{array}\right\} 48$ & F 19 & $\begin{array}{r}134 \\
94 \\
\end{array}$ & $\begin{array}{l}65 \\
51 \\
\end{array}$ & $\left.\begin{array}{l}52 \\
46\end{array}\right\} 49$ \\
\hline M 20 & $\begin{array}{r}127 \\
90\end{array}$ & $\begin{array}{l}77 \\
65\end{array}$ & $\left.\begin{array}{l}39 \\
28\end{array}\right\} 34$ & $\mathrm{~F} 20 t$ & $\begin{array}{r}100 \\
81\end{array}$ & $\begin{array}{l}49 \\
46\end{array}$ & $\begin{array}{l}51 \\
43\}^{4} \\
\end{array}$ \\
\hline M 21* & $\begin{array}{l}717 \\
707 \\
668 \\
462 \\
428 \\
\end{array}$ & $\begin{array}{l}420 \\
559 \\
411 \\
312 \\
296 \\
\end{array}$ & $\left.\begin{array}{l}41 \\
21 \\
39 \\
33 \\
31\end{array}\right\} 33$ & F $21 * t$ & $\begin{array}{l}79 \\
72\end{array}$ & $\begin{array}{l}39 \\
39\end{array}$ & $\left.\begin{array}{l}51 \\
46\end{array}\right\} 49$ \\
\hline M 22 & $\begin{array}{l}253 \\
151 \\
\end{array}$ & $\begin{array}{r}108 \\
59 \\
\end{array}$ & $\left.\begin{array}{l}57 \\
61\end{array}\right\} 59$ & F $22 * t$ & $\begin{array}{l}210 \\
255 \\
\end{array}$ & $\begin{array}{r}93 \\
131 \\
\end{array}$ & $\left.\begin{array}{l}56 \\
49\end{array}\right\} 53$ \\
\hline M 23* & $\begin{array}{l}513 \\
642 \\
624 \\
\end{array}$ & $\begin{array}{l}445 \\
542 \\
625 \\
\end{array}$ & $\left.\begin{array}{r}13 \\
16 \\
0\end{array}\right\} 10$ & F 23 & $\begin{array}{r}120 \\
94\end{array}$ & $\begin{array}{l}62 \\
54\end{array}$ & $\left.\begin{array}{l}48 \\
43\end{array}\right\} 46$ \\
\hline M 24 & $\begin{array}{l}78 \\
62\end{array}$ & $\begin{array}{l}38 \\
34 \\
\end{array}$ & $\left.\begin{array}{l}51 \\
45\end{array}\right\} 48$ & F 24t & $\begin{array}{r}99 \\
116\end{array}$ & $\begin{array}{l}67 \\
60\end{array}$ & $\left.\begin{array}{l}32 \\
48\end{array}\right\} 40$ \\
\hline$M 25 *$ & $\begin{array}{l}124 \\
123\end{array}$ & $\begin{array}{l}73 \\
75\end{array}$ & $\left.\begin{array}{l}41 \\
39\end{array}\right\} 40$ & F 25 & $\begin{array}{l}128 \\
121\end{array}$ & $\begin{array}{l}34 \\
45\end{array}$ & $\left.\begin{array}{l}73 \\
63\end{array}\right\} 68$ \\
\hline
\end{tabular}

- Cierarette smokers ( $<10 /$ day). + Post-menopausal women. malities were found in this group: the mean population systolic and diastolic pressures were $131 \pm 18$ and $84 \pm 9 \mathrm{~mm}$. Hg respectively. There was no sugar or albumin in their urine and no definite evidence of myocardial ischaemia in the preor post-exercise electrocardiograms. Of the 25 female donors 13 were post-menopausal, and the mean duration of the postmenopause in these subjects was approximately five years.

\section{Materials and Methods}

Exercise Procedure.-So far as possible the experimental conditions for this study were identical to those for the young subjects. All experiments were performed during the morning in a procedure room at $19-20^{\circ} \mathrm{C}$., and subjects were requested to refrain from smoking and excessive exercise on the morning of the experiment. Before the exercise procedure the subject rested for 30 minutes, lying down, and the pre-exercise cubital venous blood sample was then withdrawn. The exercise consisted of walking for eight minutes on a treadmill which was moving at a speed of $3.4 \mathrm{~m} . \mathrm{p} . \mathrm{h}$. at an angle of $5^{\circ}$ elevation. The post-exercise cubital venous sample was withdrawn immediately the treadmill had stopped. All subjects were studied on more than one occasion with a time interval of at least a week between separate exercise procedures.

Fibrinolytic Assay.-The techniques for blood withdrawal, centrifugation, and assay of circulating plasminogen activator by the euglobulin lysis time were as previously described (Cash, 1966), with the exception that the end-points for clot lysis were recorded on an automatic clot lysis recorder (Cash and Leask, 1967). No statistical difference was demonstrated between euglobulin lysis times when end-points were recorded visually and by the automatic clot lysis recorder (Cash, 1967). The A-B percentage fibrinolytic response was calculated as $\frac{A-B}{A} \times 100$, where $A$ and $B$ represented the pre- and post-exercise euglobulin lysis times, respectively.

\section{Initial Studies on 50 Middle-aged Subjects}

Table I shows the results in detail of all the experiments. The mean pre-exercise euglobulin lysis time was $213 \pm 193$ minutes. There was no statistically significant difference between the sexes when analysed by Student's $t$ test $(t=1.2055 ; 0.1<\mathrm{P}<$ 0.2).

The mean percentage fibrinolytic response was $46.9 \pm 13.5$. There was a significant variation between some individuals (analysis of variance showed $F=28.4$, which was significant at the $1 \%$ level), and it was possible to isolate a group of middleaged subjects whose response was consistently poor (less than $20 \%$ ). There was a significantly higher response in the female subjects compared with the male $(t=2.4822 ; 0.01<\mathrm{P}<0.02)$. Table II shows the frequency distribution of the percentage fibrinolytic response in the original young population (Cash, 1966) and the middle-aged subjects described in this paper.

TABLE II.-Frequency Distribution of Percentage Response to Moderate \begin{tabular}{l|c|c|c|c|c|c|c|c} 
Exercise in Young and Middle-aged Subjects \\
\hline & \multicolumn{8}{c}{ Percentage Response } \\
\cline { 2 - 7 } & $0-10$ & $11-20$ & $21-30$ & $31-40$ & $41-50$ & $51-60$ & $61-70$ & $71-80$ \\
\hline Young & 0 & 1 & 5 & 13 & 16 & 13 & 2 & 0 \\
Middle-aged & 2 & 1 & 1 & 8 & 20 & 11 & 5 & 2
\end{tabular}

\section{Twelve-month Follow-up Study on 18 Subjects}

Eighteen middle-aged subjects (15 male, 3 female) were restudied 12 months after the initial series of experiments. These subjects were selected by one of us (J.D.C.), who had performed 
the original tests, and studied by D.G.W. Table III shows the results of this study.

There was no significant difference in the mean resting euglobulin lysis time $(250 \pm 222$ and $289 \pm 117 \mathrm{~min}$.; $t=$ $0.6425 ; 0.4<\mathrm{P}<0.5$ ), but a good correlation between the individual mean values $(\mathrm{r}=0.8440 ; \mathrm{P}<0.001)$ when studied 12 months later.

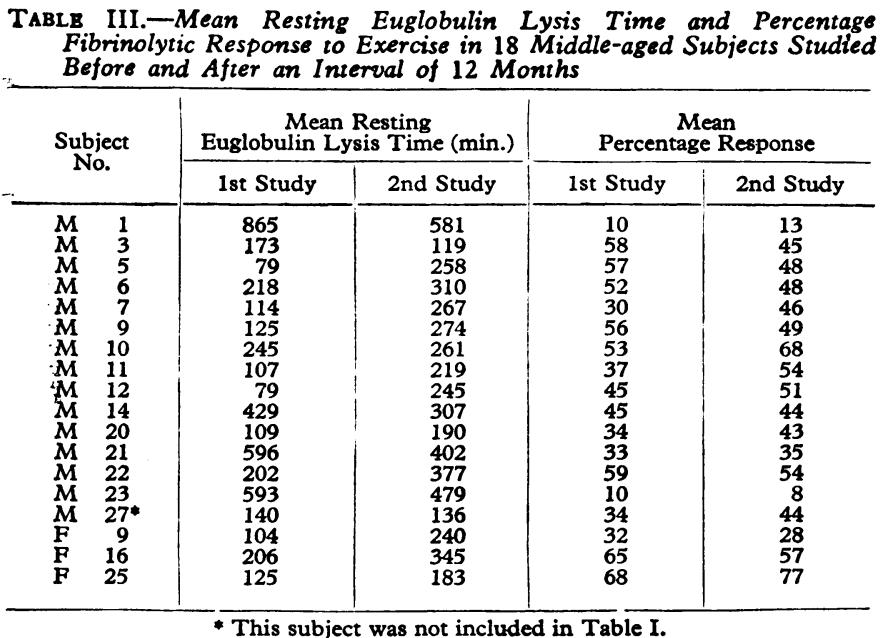

The original mean percentage fibrinolytic response to the exercise was $43.2 \pm 16.9$ and 12 months later was $45.1 \pm 16.7$. There was no significant difference between these values $(t=$ $0.3370 ; 0.8<\mathrm{P}<0.9)$ and there was a good individual correlation $(\mathrm{r}=0.8504 ; \mathrm{P}<0.001)$.

\section{Discussion}

\section{Resting Levels of Euglobulin Lysis Time}

By using the results of the earlier studies on 50 young subjects aged 18-30 years (Cash, 1966) it was possible to make certain comparisons with the present findings in the middleaged population. The difference between the mean resting euglobulin lysis times of the young $(183 \pm 103 \mathrm{~min}$.) and middleaged $(213 \pm 193 \mathrm{~min}$.$) subjects was not significant (t=0.9793$; $0.3<\mathrm{P}<0.4$ ). Previous studies on the effect of age and fibrinolysis are sparse and contradictory. Buckell and Elliott (1959) and Swan (1963) reported a diminished level with increasing age, whereas Hume (1961) observed an increase. However, our finding is in agreement with those of Sawyer et al. (1960), Fearnley et al. (1963), Moser and Hajjar (1966), and Mann (1967).

The absence of a sex difference in the middle-aged subjects is in contrast to the findings in the young subjects, in whom the females had a significantly lower euglobulin lysis time than the males $(t=2.2261 ; 0.02<\mathrm{P}<0.05)$. This observation in the middle-aged subjects was not influenced when the postmenopausal women were excluded from the statistical analysis nor was there a satisfactorily significant difference between the pre- and post-menopausal women $(t=1.8315 ; 0.05<\mathrm{P}<0.1)$.

There is fragmentary evidence to indicate that cigarette smoking may depress fibrinolysis (Gibelli ot al., 1964 ; Sogani and Joshi, 1965). A review of the histories of the young and middle-aged subjects showed a striking difference in the cigarette-smoking habits between the sexes in the two age groups. Of the 50 young subjects reported in the previous paper, $7 / 25$ male and $1 / 25$ female subjects (M1, M8, M11, M12, M13, M18, M20, and F13) smoked more than 10 cigarettes per day, whereas in the middle-aged group the cigarette smokers were equally divided between the sexes $(9 / 25$ male and $9 / 25$ female). If the non-smoking young subjects were compared then there was no difference between the sexes $(t=1.3093 ; 0.1<\mathrm{P}<0.2)$. Furthermore, the middle-aged cigarette-smoking group had a significantly prolonged mean resting euglobulin lysis time compared with the non-smokers $(t=2.4713 ; 0.01<\mathrm{P}<0.02)$, and when the total population of smokers, both young and middle-aged, were compared with the total non-smoking population this same phenomenon was demonstrable $(t=4.5917 ; \mathrm{P}<0.001)$. Though the number of subjects was small, these results emphasize the fact that cigarette smoking may prove to have a deleterious effect on the resting level of circulating plasminogen activator as measured by the euglobulin lysis time. This subject is worthy of more extensive investigation.

\section{Fibrinolytic Response to Exercise}

The results of the exercise fibrinolytic response studies in the middle-aged subjects showed certain similarities to those obtained in the young: there was satisfactory individual reproducibility, a significant variation between individuals, and the isolation of a group of poor responders. There also appeared: to be a higher response in the females than in the males $(t=$ $2.4822 ; 0.01<\mathrm{P}<0.02)$, but this was less significant than the sex difference found in the young subjects $(t=3.2076 ; 0.001<$ $P<0.005)$. Although there was no significant difference in fibrinolytic response between the pre- and post-menopausal women $(t=0.1293 ; 0.8<\mathrm{P}<0.9)$ it is of interest to note that one of the middle-aged poor responders was a post-menopausal woman-no poor responders were demonstrated in the young female group. It is possible that the marked sex difference in fibrinolytic response to exercise seen in the young subjects may diminish later in life, but no firm conclusions are yet possible. Cigarette smoking appeared to have no influence on the fibrinolytic response to exercise.

From other sources evidence is available which shows that with increasing age there is a concomitant increase in energy expenditure for any fixed submaximal exercise procedure (Becklake et al., 1965; Hanson et al., 1966), and that this phenomenon is not associated with a higher pulse rate response in the older subjects (Astrand, 1958 ; Strandell, 1964). It has also been shown that the fibrinolytic response increases with increased severity of the exercise (Cash, 1967 ; Menon et al., 1967). In view of the expected higher energy expenditure in the middle-aged subjects, the finding of no statistically significant difference in fibrinolytic response between the two age groups $(t=1.1995 ; 0.2<\mathrm{P}<0.3)$ may therefore prove to be of some significance. More detailed studies are required in which subjects are compared after exercises of comparable energy expenditure; such a project would prove to be formidable.

The observed absence of a significant change in the mean pre-exercise euglobulin lysis time and the fibrinolytic respenses to the same exercise procedure in 18 of the middle-aged subjects 12 months after the original experiments was both interesting and gratifying. Despite the fact that this study was performed by a different team of technicians, who had no previous knowledge of the earlier results, the phenomenon of a poor fibrinolytic response to exercise was substantiated and there was a good correlation in the individual responses of the other subjects.

We are, as yet, no further forward in understanding the pathophysiological significance of the fibrinolytic response to exercise. It is important to emphasize that this phenomenon is probably a measure of both the release and the removal of circulating plasminogen activator. Furthermore, in-vivo thrombolysis is not necessarily entirely dependent on the absolute level of plasminogen activator, for the ability of activator to dissociate from its antiactivator, the rapidity with which it can then be adsorbed into the clot, the intra-clot concentration and reactivity of plasminogen, antiplasmins, and antiactivators may also prove to be important factors contributing to satisfactory in-vivo clot dissolution. It is of interest to record that 
during the preparation of the 12-month follow-up programme we observed defirite ischaemic changes in the post-exercise electrocardiogram in one of our poor responders-changes which were not present 12 months before. However, one of our original good responders $(68 \%)$ died after a posterior myocardial infarction in the 12 -month interval. Necropsy showed widespread coronary artery atheroma, and on microscopical examination of the thrombus in the right coronary artery it was found that this was probably secondary to haemorrhage into an atheromatous plaque.

\section{Summary}

The resting levels of circulating plasminogen activator, as measured by the euglobulin lysis time, and changes following a standard exercise procedure were studied in 25 male and 25 female healthy middle-aged subjects. There was a significantly higher level in the female group. Comparison with previous results obtained from 50 young healthy subjects aged 18-30 years showed no statistically significant difference between the two age groups. There was evidence to indicate that cigarette smoking may have a deleterious effect on the resting level of circulating plasminogen activator.

The phenomenon of the poor fibrinolytic responder to exercise, previously described in the young subjects, was also shown in the middle-aged population. The middle-aged females had a significantly higher response than the middle-aged males, but there was no significant difference between the total young and middle-aged populations. Cigarette smoking had no influence on the fibrinolytic response to exercise.

A 12-month follow-up study on 18 middle-aged subjects confirmed the phenomenon of a poor fibrinolytic response to exercise.
We wish to thank our enthusiastic group of blood donors; Dr. R. A. Cumming, Director of the South-east Scotland Regional Blood Transfusion Centre, for his sustained interest and helpful advice; Professor K. W. Donald, University Department of Medicine, for treadmill facilities; Dr. A. E. Robertson and her staff, who were responsible for the recruiting of the blood donors; and $\mathrm{Mr}$. A. G. E. Allan, Miss M. Newbigging, and Miss P. Scott for their technical assistance. Our thanks are also due to Dr. N. McLean, pathologist of the Western General Hospital, Edinburgh, who permitted us to quote his necropsy report. This research programme was supported by a grant from the Scottish Hospital Endowments Research Trust.

\section{REFERENCES}

Astrand, I. (1958). Acta physiol. scand., 42, 73.

Astrup, T. (1956). Lancet, 2, 565.

Becklake, M. R., Frank, H., Dagenais, G. R., Ostiguy, G. L., and Guzman, C. A. (1965). \%. appl. Physiol., 20,938.

Buckell, M., and Elliott, F. A. (1959). Lancet, 1, 660.

Cash, J. D. (1966). Brit. med. f., 2, 502.

Cash, J. D. (1967). The Stimulation of Fibrinolytic Activity in Man, Ph.D. Thesis, Edinburgh University.

Cash, J. D., and Allan, A. G. E. (1967). Brit. F. Haemat., 13, 376.

Cash, J. D., and Leask, E. (1967). F. clin. Path., 20, 209.

Fearnley, G. R., Chakrabarti, R., and Avis, P. R. D. (1963). Brit. med.

Gibell, 1, A., Bolandrina, E., Del Favero, A., and Pasotti, C. (1964). G. Geront., 12, 31

Hanson, J. S., Tabakin, B. S., and Levy, A. M. (1966). Brit. Heart f., 28, 557 .

Hardaway, R. M. (1966). Syndromes of Disseminated Intravascular Coagulation. Springfieid, Illinois.

Hume, R. (1961). f. clin. Path., 14, 167.

Mann, R. D. (1967). F. clin. Path., 20, 223.

Menon, I. S., Burke, F., and Dewar, H. A. (1967). Lancet, 1, 700.

Moser, K. M., and Haijar, G. C. (1966). Amer. f. med. Sci., 251, 536.

Sawyer, W. D., Fletcher, A. P., Alkjaersig, N., and Sherry, S. (1960). \%. clin. Invest., 39, 426.

Sogani, R. K., and Joshi, K. C. (1965). Indian Heart F., 17, 238.

Strandell, T. (1964). Acta physiol. scand., 60, 197.

Swan, H. T. (1963). Brit. F. Haemat., 9, 311 .

\title{
Hand-foot-and-mouth Syndrome in Humans : Coxsackie A10 Infections in New Zealand ${ }^{*}$
}

\author{
M. F. DUFF, $\dagger$ M.sC.
}

Brit. med.F., 1968, 2, 661-664

\section{Historical}

On 19 April 1957 J. H. Seddon (personal communication, 1965) submitted a report to the Research Committee of the New Zealand Council, College of General Practitioners, describing eight cases, in children, of a new clinical illness which has come to be known as hand-foot-and-mouth disease (Alsop et al., 1960). The outbreak occurred in the Mangakino district of the North Island of New Zealand. No virological studies could be done at the time. This original report was later published when the college began issuing a research newsletter (Seddon, 1961). There is evidence, however, that the disease may have been observed many years before this but confused with and taken for the bovine foot-and-mouth disease (Flaum, 1939). In 1958 Robinson et al. published the results of an investigation of 60 cases of the same disease which occurred in Toronto, Canada, from late June to early July of 1957. They isolated Coxsackie A16 strains in suckling mice and tissue cultures. Reports of similar outbreaks in other countries throughout 1959, 1960, and 1961 soon followed (Alsop et al., 1960; Magoffin

\footnotetext{
* This investigation was carried out at the National Health Institute, $52 / 52$ Riddiford Street, Wellington, New Zealand.

t Department of Microbiology, Massey University, Palmerston North, New Zealand.
}

et al., 1961 ; Stewart, 1961 ; Flewett et al., 1963). The strain most commonly isolated was Coxsackie A16 (Alsop et al., 1960 ; Magoffin et al., 1961) but Coxsackie AS was also isolated (Flewett et al., 1963), the viruses propagating in suckling mice only. Recovery of the latter from one specimen of vesicle fluid added stronger evidence that the disease was of viral origin (Flewett et al., 1963).

In May 1961 the disease was again reported in New Zealand, when 40 cases, mostly children, were seen (Anyon, 1961). Interest was stimulated in this new and interesting syndrome, and throughout 1963 and up until January 1964 numerous outbreaks were reported throughout England and Scotland (Abrahams, 1963 ; Crow et al., 1963 ; Fletcher, 1963 ; Lipp, 1963 ; Meadow, 1963 ; Palmer et al., 1963 ; Tattersall, 1963; Clarke et al., 1964 ; Erskine and Griffith, 1964 ; Trowell, 1964). From the limited number of isolations attempted Coxsackie A16 once again appeared to be the strain most prevalent (Higgins et al., 1965), but some Coxsackie A10 strains were also isolated (Clarke et al., 1964). The viruses propagated in suckling mice only.

Outbreaks of the disease also occurred in the U.S.A. in the summer and fall of 1963 (Richardson and Leibovitz, 1965; Cherry and Jahn, 1966). Both articles report the isolation of 